\title{
Re-entering the house
}

\section{Scenographic and artistic interventions and interactions in the historic house museum}

\author{
HEDVIG MÅRDH
}

\begin{abstract}
Scenographic and artistic interventions and interactions have gained in significance within the fields of exhibition and museum design since the 1990s. This article specifically focuses on historic house museums, and how they use their theatrical and scenographic assets in order to recharge and reinvent themselves. The author discusses the different aims and tasks these interventions and interactions take on, and the attitudes that make them happen. Further, the author argues that the field of art history should address these changes in museological practice, and should investigate new possible readings of the historic house, the objects within, and artistic interventions. This would also show the relevance of art history to the field of critical heritage studies in a period that is characterized by the heritage boom and the new experience industry.
\end{abstract}

Keywords: Historic house museum, art history, authenticity, museology, materiality, scenography, contemporary art, Dennis Severs' House, Kensington Palace, Carl Eldhs Ateljémuseum.

Lemons peeled and put in the punch bowl. Piss in the chamber pot and the un-made bed. Soft music, and the sound of carriage wheels rattling against cobblestones. The family has just left the room. Where have they gone, and what have they left behind? I sense a story, I can almost grasp it, and clues are left as smells, notes, and the imagined reminiscence of movement and life. ${ }^{1}$ In the documentary The house that wouldn't die, the artist David Hockney referred to his visit to Dennis Severs' House in Spitalfields, London as: "Just stunning. It is a stunning, fantastic experience, actually. It was a bit of theatre; it was a bit of a museum. But, I mean it was unique, I mean, I don't think I have had an experience like that since" (BBC4, 2005).

In the same documentary, the presenter Dan Cruickshank comments on the role of the art historian: "I guess it is easy for the art historian to pickle this to pieces", i.e. "not really get it", suggesting that an art historian wouldn't really get beyond the question of authenticity. Perhaps this is the case; the field of art history might not have the analytical tools or the right outlook to understand or incorporate a house such as this. Traditionally, art historians have studied historic houses through plans, 


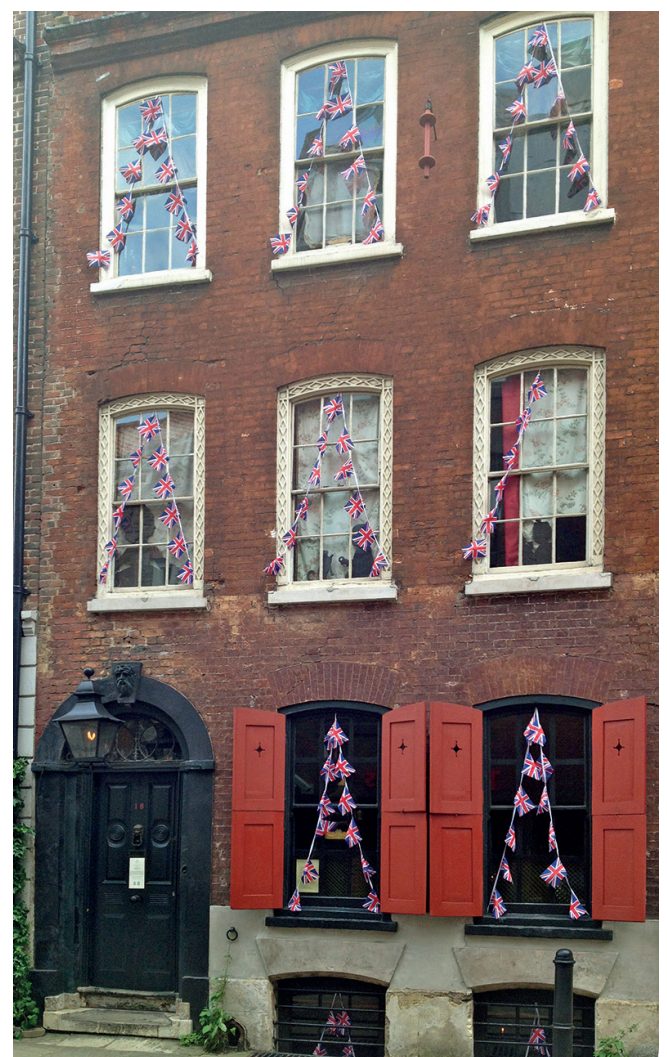

Fig. 1. The exterior of Dennis Severs' House at 18, Folgate Street, London decorated with flags during the summer of 2013. The Museum of British Folklore held an exhibition in the house in which they collaborated with the London based artist Richard Sharples and sound artist Richard J. Lockley-Hobson, who produced a series of "Rare Boxes" that told tales from London folklore. Photo: Hedvig Mårdh, 2013.

drawings, inventories, and individual objects, and have greatly contributed to the concept of period rooms both in museums and historic houses. At the beginning of the 20th century, aesthetic considerations, a stylistic canon, and the structures of city planning were the primary interests for art and architectural historians. This perspective has also been mediated through guide literature, historical societies, and the conservation movement to this day. This traditional role has coincided with the popularity of the museological concept of the period room, which has played an important role in both museums and historic houses, as well as within the discipline of art history. Rosanna Pavoni, the former president of DEMHIST (ICOM's International Committee for Historic House Museums), described the period room as a "simplified syntheses of an artistic style and taste" (Pavoni 2001:16). Admittedly, the period room is a place where an art historian can feel at home; it is a stage, which is managed to portray a pure state, connecting stylistic and historical considerations.

However art historians can, and have, taken on different professional roles and adopted new perspectives. Numerous art historians work as museum professionals and many have dedicated their lives to historic houses, managing and staging them for visitors. Moreover, as a professional group they have been part of and been affected by a museological practice that has changed over the past century. For example, by the 1980s the period room had fallen out of fashion, especially among curators (Bryant 2007:345). Curators started to question the authenticity and capacity of the period rooms while the public interest in living history increased, and demands for democratization and inclusion became part of the agenda. At this point, the academic discipline of art history had also substantially changed. What had happened was that human usage had become more important, and curators had to find new ways to fill the historic houses with life. 


\section{Changing museological practices}

This article demonstrates how changes in museological practice in historic houses can spur new questions and perspectives and open up new fields of study, challenging notions of both contemporary arts and the emerging field of visual critical heritage studies. ${ }^{2}$ The historic houses described in this article, Dennis Severs' House and Kensington Palace in London and Carl Eldhs Ateljémuseum in Stockholm, have all been chosen because they illustrate these changes. ${ }^{3}$ Furthermore, they all suggest a trend, one where historic house museums increasingly use their potential as creative spaces in order to recharge and reinvent themselves. One way of accomplishing this undertaking has been to invite artists and scenographers to comment, challenge, and develop the theatrical and scenographic assets of these spaces. The artist Fred Wilson's exhibition Mining the Museum at the Maryland Historical Society in 1992 is often referred to as the starting point for these kinds of interventions. Numerous actors are involved in the interventions: curators, artists, visitors, galleries, critics, tourist organizations, governmental support for the arts, local interest groups, filmmakers, academics, and many more. This practice is partly initiated by new challenges for historic house museums. These challenges include new perspectives brought on by the influence of "new museology", which has made curators increasingly aware of a history of power that could be addressed by a new set of norm critical approaches inspired by, for example, gender studies and postcolonial studies (Vergo 1989, Marstine 2008). It also prompted an awareness of potential new visitor groups. Another consequence has been the attention paid to the homes of the less privileged, resulting in a more diverse combination of historic houses opening up to the public. Examples of these include the in 1992, telling the stories of numerous immigrants, and the collection of museum apartments cared for by the Stockholm City Museum, which present the diverse history of the city. This is a development that has coincided with the heritage boom and the expansion of the experience economy. Today, many museums have become part of destination making strategies, offering premier attractions with vigorous programs of events (Kirshenblatt-Gimblett 1998:132).

The historic house museum has become interesting as a creative space precisely because it is not a white cube or a museum built for art exhibitions, but is rather the home of people from the past. These characteristics open up for numerous strategies for artists, scenographers, and curators. Other art forms, which take place in these creative spaces, away from the white cube, are literature, film, and the performing arts, such as theatre and dance. However, these will not be commented on to any great extent in this article. ${ }^{4}$ The interest in scenographic and artistic interventions has been reflected at recent conferences and seminars covering the preservation and interpretation in historic house museums. To mention a few recent examples: at the annual international DEMHIST conference in Antwerp, 2011, the theatrical assets of the historic house museum were in focus. In November 2014, about forty people, art historians and professionals within the field, met at Uppsala University to discuss art history and its role in the historic house museum. ${ }^{5}$ Moreover, interventions have been recognized as a strategy at a national level as well, for example the Arts Council in the UK and its project museumaker (2009-11) where artists related to both the collections and the buildings in their works. The project "worked 
28 to achieve long-term sustainable change in the way the historical is brought to life by the contemporary" (Arts Council England 2011). Despite this apparent interest and their popularity, there has still been little research within the fields of art history or critical heritage studies about this phenomenon of scenographic and artistic interventions. ${ }^{6}$

\section{THE HISTORIC HOUSE MUSEUM}

The historic house museum is a very specific exhibition space, sometimes not even referred to as a museum, and not always that easy to place into a category. ${ }^{7}$ It can be concerned with cultural history, art history, community history, and much more. House museums can comprise all kinds of scales and orientations; in addition, they have different museological and technical museographic constraints than other types of museums. ${ }^{8}$ Dennis Severs' house at 18 , Folgate Street, can be described as both a skilfully created scenography and as an artwork. However, any way you chose to describe it, it is not a museum in any traditional sense. Dennis Severs never meant for it to be an objective, authoritative history. Instead Severs described himself as an artist and his house as an artwork, a Gesamtkunstwerk.

Nevertheless, his house has had a major influence on conservation bodies and historic house museums as an inspiration for how to bring life and atmosphere into a house. ${ }^{9}$ In Dan Cruikshank's documentary, mentioned earlier, several distinctive features of the place are identified as part of what makes it work: it is personal, it evokes strong emotions, and it breaks the rules.

House museums have the great potential and power of being a "real place" filled with an excellent collection of real things, or at least that is how we usually understand them as visitors (Moore 1997:137). Kevin Moore refers to them in Museums and Popular Culture as having "the power of the three": the real thing, the real place, and the real person. They are filled with the traces of those who lived and used the houses, and the objects can help in transmitting their relations to these people. According to Jessica Foy Donnelly, a historic house has the advantage of being a "universally understood place" since we all can relate to the concept of home. It creates a recognition, which good interpretation should build on (Donnelly 2002:3). It makes us as visitors wonder about the place and what other persons have moved through the same spaces, comparing them to ourselves. This is a comparison that evokes feelings of empathy as well as providing knowledge about the past. Still, these powers, although they might go a long way, are not enough in themselves. They need to be managed, maintained, and staged. Some of the main characteristics of a house museum can even pose a problem in terms of communication with the visitor; the house can feel fossilized. Normally, collections in historic houses don't change much, and there is little flexibility of space. This stability might convey the false impression of these houses as being untouched and untouchable; luring us into believing that they are objective displays of the past. Many curators are acutely aware that the past cannot be accurately reproduced because it has never been a concrete entity. There is always the act of selecting from the past, to create a sense of pastness.

This strong sense of being real and true is both a blessing and a curse to the historic house museum. This is especially true if you recognize that the meaning and value of the objects should be produced through their interaction with the visitor. As museum director Mónica Risnicoff de Gorgas puts it: "Objectivity does 
not exist in the exhibition given that each object is displayed as an interpreted object, with emphasis being placed, in some form or other, on certain aspects" (Risnicoff de Gorgas 2001:11). The historic house and the objects therein are ascribed meanings by curators, art historians, and others. However, if you let them, they also have the power to oppose these meanings and tell completely different stories to visitors or even through visitors. So far, most of the interventions have been more or less celebratory in their character. However, this does not mean that the curator cannot aim for a change of perspective. How do we bring these stories out? Most of these houses represent the history of the privileged classes, and even though efforts have been made to widen the selection to include the homes of ordinary people, this is still an exception. This situation suggests that many curators face the challenge of bringing out stories that remind us that everyone did not share the opinions and lives described in the main narrative. These "new" stories might result in a total reinterpretation of the site, or they might be integrated as subtle footnotes.

The experience of time is complicated in all museums. Traditionally, the period room is based on chronology and on a linear conception of time, and the displays highlight specific stylistic moments. However, a historic house can be more than a time capsule - it can be turned into a time machine. A historic house museum challenges the passing of time by its very existence. Materially it is taken out of orbit, preserving a piece of the past. Sometimes the visitor looks at this time capsule and marvels at what has been. Other times the visitor travels in time, not to any specific point but rather back and forth, between then and now. Although museums depend on timelines and chronologies historic house museums tend to oppose timelines. In a historic house art and objects might be experienced simultaneously rather than as singular occurrences along a timeline. The current director of 18, Folgate Street describes Severs' creation as "a time machine lit only by candle light and heated by open fires" (Milne 2012:44). What's more, the notion of time is interesting because the present is always changing, and we can not know who a future visitor is and what he or she will expect. The only conclusion we can draw is that we will understand the historic house and its past differently at each specific time we return to it, since it is always the present that dictates our understanding.

\section{TELLING STORIES THROUGH SCENOGRAPHY}

Scenography is the discipline of narrative spaces and spatial choreographies. Through scenography, the curator can manipulate and control the experience of the visitor. Visitors in historic houses normally experience the house through the house tour, an interpretive tool that requires its own scenography and choreography. This basic idea is also present in 18, Folgate Street. However, since there is no guide, it is the visitor that dictates the pace and order in which to enter the rooms. The objects themselves, the scenography and choreography that act and shape the experience, deliver a story that is always present and sensed. This scenography of the house itself can be enhanced or challenged in different ways.

A scenographic intervention might turn out to be a total redesign of the experience, which was the case in The Enchanted Palace at Kensington Palace. This project came about as the result of construction at the palace, which ended up creating a feeling among the management and the curators "that they 
30 were on the cusp of a greater shift in their ambition" (Barnes \& Marschner 2012:85). The curators John Barnes and Joanna Marschner describe the two-year project (2010-12) as an imagined world that helps to tell seven stories about seven princesses. "It's not an exhibition, or a display or a performance. It is a multilayered collection of inspiration using many different media and it engages the visitor on a quest which draws them through this very complicated site making discoveries" (Barnes \& Marschner 2012:85). In order to create this elaborate scenography and performance, Kensington Palace involved partners such as theatre makers, a poet, fashion designers, and an illustrator and set designer.

Visitor and critical reception varied. Some were very disappointed and surprised - this was not what you expected when you visited a royal palace. The rooms were dark, and you couldn't see the palace itself. ${ }^{10}$ These disappointed visitors seem to have expected a traditional presentation, and were not at all interested in engaging with the performance. Some seem to have been bemused, unsure what to make of it, "so peculiar it is as if you've stepped into Tim Burton's 'Alice in Wonderland' [...] the multisensory display is a truly surreal experience" (Battersby 2010). Others were thrilled with the new way of experiencing a palace. The Guardian, quite tellingly, included their review of the project in the theatre section, and was largely positive. "Operating at the interface between history and imagination, museum and installation, theatre and the theatrical spectacle of royalty..." (Gardner 13 April 2010) The curators were aware that the project would be a risk, and realized that some traditional visitors might be disappointed and not come back. However, the experience seems to have been useful for the organization, "it has been a wonderful opportunity to experiment and to develop the capabilities of the in-house team and to make further creative leaps when the next opportunity arises. A project like this one requires a leap of faith" (Barnes \& Marschner 2012:86). But how do you take the audience along with you in this leap of faith?

\section{ATMOSPHERE AND EMPATHY}

When entering 18, Folgate Street, and after "passing through the surface of the painting", you have to surrender yourself to the rules of the house. You are only allowed to enter if you turn off your phone, promise to keep quiet, and not take any photographs. Once inside, there are numerous appeals, or orders if you like, to "Pay Attention!" as well as rather rude remarks "Either you get it, or you don't!" Most who enter the house are aware of these conditions before deciding to go there. Probably it is part of the lure of the place, and you are prepared to experience something different, out of the ordinary. This gives the experience a sense of exclusivity.

Dennis Severs named his unpublished guidebook The Space Between, and instead of focusing on a display of authentic originals, he worked with creating atmosphere and empathy. "He felt able to summon up past eras, not through history books, but through empathy with objects and places, to tell a fictional, true story", as the architectural historian Gavin Stamp puts it (Stamp 2000). Severs' attitude can also be understood in the light of what museologist Peter van Mensch has written about the space inbetween the material fabric of the historic house. He argues that this space works as "the metaphorical spirit of the place", something that holds the components together (van Mensch 2012:14).

What was the context in which this house came into existence? Dennis Severs was an 


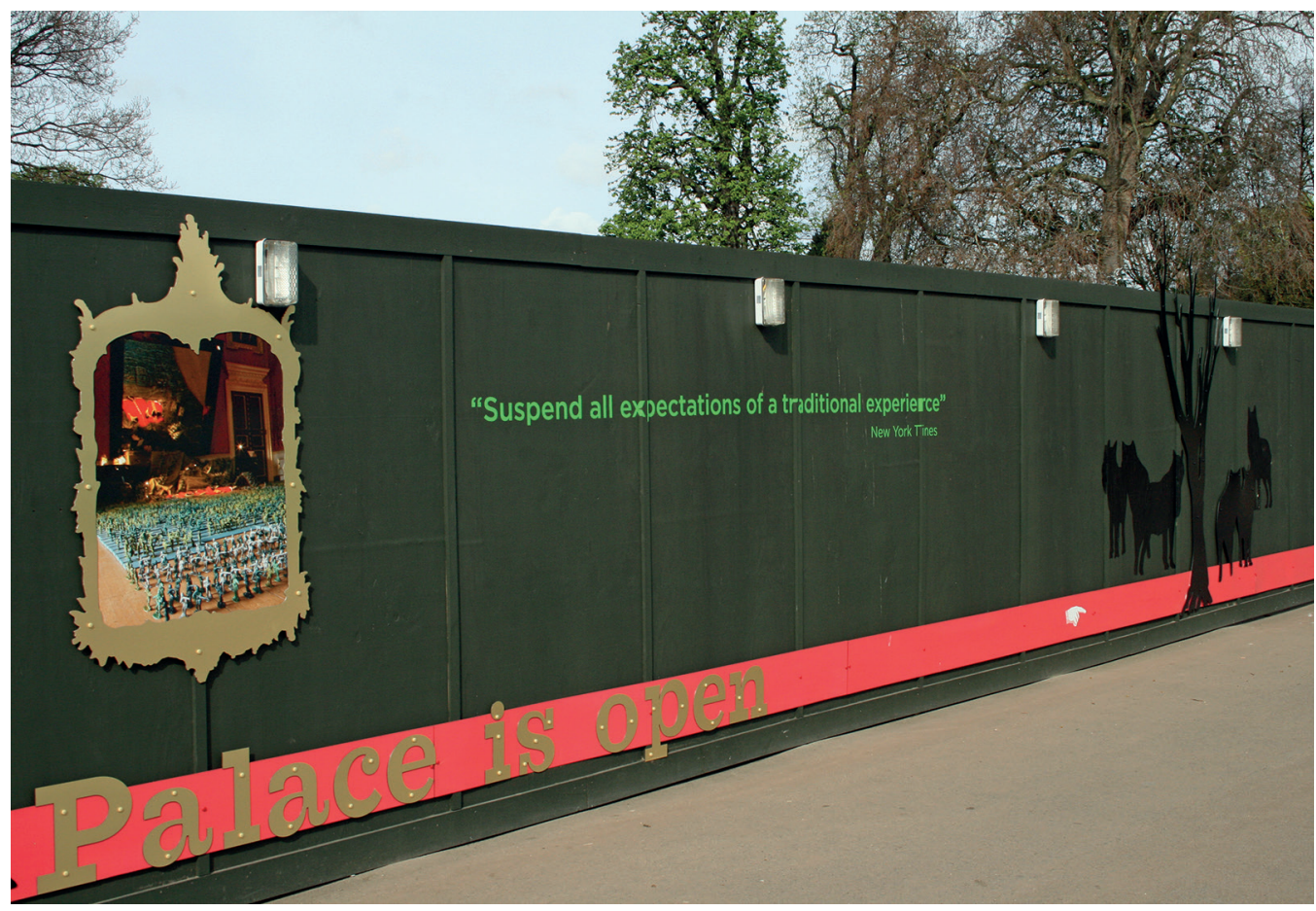

Fig. 2. "Suspend all expectations of a traditional experience" - behind the fence a major restoration was carried out at Kensington Palace in 2011, a restoration that instigated The Enchanted Palace. Photo: Hedvig Mårdh, 2011.

American who moved to London in the 1970s. He lived in 18, Folgate Street in Spitalfields for twenty years (1979-99), creating a unique home that is now open to the public. Severs was part of a group of people, sometimes referred to as the Neo-Georgians, who began renovating houses in Spitalfields in the 1980s. Living in the same area were the artists Gilbert and George and the historian and writer Raphael Samuel. The preservationists formed the Spitalfields Historic Building Trust, which still is active. Critics such as Patrick Wright described this period as "the days of art-historical activism". This activism later contributed to a gentrification of the area, and house prices today are staggering (Wright 2009:119). What happened in Spitalfields in the 1980s was part of the growing heritage movement in the UK at the time (e.g. in 1980 the National Heritage Act went into effect). Severs, however, did more than restore the house. He turned his house into a time capsule, a fantasy, recreating the imaginary lives of people who had just left the room. As a visitor, you travel through time while moving through the house - from the privileged life of the 18th-century dwellers in the parlour to the scanty conditions of the 19th-century lodgers living on the top floor. 
32 It is scenography and artwork combined. As the current curator David Milne reflects: "This became Dennis' art, a type of theatre unique and rare" (Milne 2012:44).

Today, Dennis Severs' house belongs to a group of somewhat quirky historic houses and museums that have become increasingly popular. It is no more historically correct than a Brontë movie. However, it was never meant to be an objective authoritarian history (BBC4, 2005). Moreover, Dennis Severs' House doesn't call itself a museum, and it is admittedly difficult to categorize. Severs himself referred to the experience offered as "still-life drama" (Dennis Severs' House 2014). In Dennis Severs' obituary in The Guardian in January 2000, Gavin Stamp defined the house as "a three-dimensional historical novel, written in brick and candlelight in Spitalfields" (Stamp 2000). Emma McEvoy referred it to as a "piece of gothic performance" in her article in Visual Culture in Britain (McEvoy 2011). Silke Arnold-de Semine, a researcher in museum studies and memory studies, refers to 18, Folgate Street as a post-nostalgic museum, where we meet nostalgia in a self-reflexive and ironic form (Arnold-de Semine 2013:135).

\section{Art in dialogue with the Past}

Displaying contemporary art in historic houses and gardens has become a trend in the last twenty years or so. The artwork and the historic house relate to each other in ways that have implications for how they are communicated, experienced, interpreted, and received. Studying the interaction between contemporary art and historic houses allows for new perspectives on how the physical character and history of a space influence our experience of an artwork. The historic house museum as exhibition space is not like that of a gallery or museum but is closer to the many re-used palaces of Italy or the numerous industrial spaces. As Sir Nicholas Serota, Director of Tate claims, they are spaces "in which dialogue between the past and present creates tension and resonance, especially when the artist responds directly to the volume" (Serota 2001:15). Serota ended a lecture held at the Royal Society for the encouragement of Arts, Manufactures and Commerce by stating that these spaces don't compete with the art. However, historic house museums are more than "volume" and do compete with anything placed in them, including art. The historic house involves a different type of agency than a regular exhibition space. However, what exactly the house can bring to art varies from house to house. It also depends on the artwork; the house can act as an assertive backdrop or as an integral part of the work. The historic house has a tangible history, including people from the past, owners, architects, artists, workers, etc. that the artist can enter into a dialogue with or try to leave out. In the meeting between contemporary art and a historic house, museum art usually takes on an instrumental role in acting as comment on or entering into dialogue with the house.

Installation-based artistic practices are those most commonly seen in interventions and interactions with historic house museums, but this does not have to be the case. Artists might approach the task very differently. Some artists, such as Fred Wilson, have museums as subject for their work, while others do not focus on museum history or museological practices at all. Art interventions and interactions in historic house museums have shown to be an effective strategy in exploring the gaps between the objects and to create important linkages between them. Curators might need help to see these links. The links also affect the 
objects themselves, suggesting new readings or re-evaluation. This meeting between the past and the present, between contemporary art and the historic house, has in some cases become a reoccurring feature, drawing both visitors and critical responses. The exhibitions, which have featured contemporary artists at Château de Versailles, have received major attention since their start in 2008. Every year Versailles has hosted exhibitions of major contemporary artists such as Jeff Koons and Takashi Murakami. On the website of Château de Versailles Spectacles, these exhibitions are described as a fascinating confrontation between baroque and contemporary art. "These encounters, sometimes emphasising contrast and synthesis, show Versailles as a living site always open to creativity" (Château de Versailles). Many of these installations have been in the gardens, but also in the palace, in spaces that already feature artworks from the past. Reception has been varied, depending on the artist but also on the perspective of the critic, creating headlines such as "King of kitsch invades Sun King's palace" (Jeff Koonsexhibition 2008), "Let them eat manga: How Takashi Murakami introduced Japanese kitsch to the Palace of Versailles" (Takashi Murakamiexhibition 2010) (Chrisafis 2008, Wingfield 2010). However, any horror or outrage is only viewed as part of the artwork. The instrumental role of the exhibition is to create headlines that make visitors ask "I wonder what is happening at Versailles today?" When it is successful, this type of exhibition has contributed to the ancient brand of Versailles, filling it with a sense of creativity and life. From an art historical point of view, it might help us understand both contemporary art and the palace and its objects in a new way.

When Carl Eldhs Ateljémuseum in Stockholm reopened in 2013 (it first opened in 1963), the Swedish artist Charlotte Gyllenhammar was asked to create an exhibition for the site. The museum was the studio and home of the sculptor Carl Eldh (1873-1954). It displays many of his works and shows his creative process through displays of tools, sketches, and models. Gyllenhammar's exhibition was the first after the re-opening, confirming a commitment to contemporary art exhibitions in the museum. It was also the inauguration of a new exhibition space, constituting part of the museum. This extra space for temporary exhibitions is a common feature in historic house museums, allowing for greater curatorial freedom, and offering a "neutral" space separated from the subjectivity of the historic house itself. Gyllenhammar's work focused on the sculptural process, and she decided to place one of her works in the studio of Carl Eldh. It was a sculpture of a girl turned upside down, and the black wax of the sculpture was in contrast to the lightness of the studio. The studio is also where Gyllenhammar acted out a performance The Mouth of the Stone together with the artists Johan Strandahl and Magnus Dahl. The performance commented on the process of sculpting, and tools made of plaster were used on a large piece of stone, breaking in the process. The curator described the installation as creating a tension with Eldh's studio, a dynamic relation between our time and that of Carl Eldh. The only restrictions were financial and that nothing in the museum should be damaged. ${ }^{11}$ The museum's exhibition description states that Gyllenhammar brings out what is invisible and absent in the studio environment. "A lot of what we thought we knew is turned on its head" (Carl Eldhs Ateljémuseum). This must also have been the intent, bearing in mind that twenty years earlier in 1993, at the beginning of her career, the same artist had made a similar intervention 
34 and created an exhibition in the former home of Carl Milles, Millesgården in Stockholm. She took over his studio, making it her own, denying the visitor access to Milles' studio; the installation was titled Haunted. However, this was a much more controversial intervention in a historic house than the more subtle language of her work in Carl Eldhs Ateljémuseum. The critics were positive, identifying the links between the two artists, both sculptors. Johanna Persman poetically ends her review with the words "they hand over their stories to each other" (author's translation, Persman 2013). The writer (anonymous) at the webjournal $C$-print commented on the interaction between artwork and site, and how it brings life and the feeling of ongoing work into the studio: "While the ethereal space independently might evoke the perception of a space where time's stood still since Eldh, it's clear Gyllenhammar's concepts aim to present the studio as a vivid space which excludes continuity and ongoing work which in essence outlines the new collaborative direction of the museum" (Anon. C-print 2013). Bringing contemporary art into the museum seems to have added a sense of relevance to the museum at a time when economic constraints make survival difficult. Two more exhibitions, both involving women sculptors, followed the Gyllenhammar exhibition. Museum director Åsa CavalliBjörkman states that most visitors were positive, and that there was a major increase in visitors. Moreover, these exhibitions inspired the museum to add a sound installation in its permanent exhibition.

\section{NEgotiatiNg THE INAUTHENTIC}

When visiting 18, Folgate Street, one's visual pleasure is immediate and striking, and the atmosphere induces you with the feeling of authenticity. But, as Dan Cruikshank suggests, it is difficult not to start to "pickle this to pieces" when your intent is academic. Most scholarly interest within art history, as one would expect, is directed towards the authentic object. However, if we pay closer attention to the material context as such, we would have to acknowledge the significance of the inauthentic.

Museums have in many ways taken on the role of gatekeepers of authenticity (HackforthJones \& Aldrich 2012:9). "Researchers and learned societies turned their attention towards the idea of achieving a quasi-scientific degree of accuracy in the reconstruction of lost interiors - and, by extension, lifestyles - of the past" (Hackforth-Jones \& Aldrich 2012:123). However, museums have been known to include copies in their collection, especially in the early history of museums and if the museum has a clear pedagogical purpose. In addition, making or endorsing replicas of its collection is a familiar occurrence in most museums and historic houses, and might be firmly embedded in the pedagogical vision of the museum. In a historic house, replicas might give visitors the freedom to move around and touch objects in a room, giving a more authentic experience of the house and its physical space. Thus, the instructional use of an object can be of greater value than its authenticity of period and provenance. The institution might also endorse the production of replicas or copies aimed at a commercial market. These are objects that bolster the prestige of the companies involved, and the visitor can even bring home a piece of the museum. Thus, the production of replicas and copies make the objects of history mobile; they act as the embodiment of a promotion of an aesthetic agenda, and once more they become objects of circulation.

Anne-Marie Hede and Maree Thyne, both 
academic researchers within the field of tourism and marketing, have explored how the inauthentic is negotiated in the context of a literary heritage museum in New Zeeland (Hede \& Thyne 2010:686). They found that the visitor could overcome the absence of indexically authentic artefacts. Indexical authenticity suggests there is a connection with facts; an index can help us separate a fake from an original. An iconic authenticity, on the other hand, suggests that objects only resemble the original; it is similar or represents something else. Both types of authenticity can be combined in the historic house, and as visitors we can negotiate paradoxes and conflicting messages rather well, as "authenticity is an assessment made in a particular context" (Hede \& Thyne 2010:689). Even though the inauthentic or fake may be experienced as dissonance, the consumer seems to be very well prepared to negotiate this. Rather, the inauthentic can be a substitute for the real or for genuine experience. The visitor or customer might even prefer it. Hede and Thyne argue that the fabricated or staged authenticity is usually required in order to supply the visitor with the feeling of an authentic experience.

This negotiation of authenticity is evident in 18, Folgate Street, where no one tells the visitor what is what, who is who, or whether it is fake or not. However, in this house it is possible to negotiate the paradoxes, and the original material is not a prerequisite for a feeling of authenticity. A careful and personal scenography helps negotiate any dissonance created by either the inauthentic or the discrepancy between the visitor's expectations and what is staged at the site. Imagination, memory, and nostalgia help the visitor to negotiate the inauthentic. They also help create an emotional attachment to the museum and the people who, in this case, never lived there.
THE MATERIALITY OF THE HISTORIC

\section{HOUSE}

In 18, Folgate Street the owner left a house ready for visits from start, offering a story and choreography for us to follow. The house is filled with objects, acquired, collected, received, and made by Dennis Severs. They are old and new, real and fake, beautiful and vulgar, but perhaps most to the point, chosen by him. Through the process of interacting with things people create themselves, something that becomes apparent to us in the interiors of our homes. Consequently, objects might work as representations, visual constructs, holding the agenda of the maker or owner while at the same time they are susceptible to manipulation by a curator, artist, or visitor. In this sense, objects are always open to presentations that work outside the agendas for which they were conceived. This is also true in our reading of them; different perspectives make the objects tell different stories.

The trajectories of the objects that make up the scenography in a historic house may look quite different. In the case of a private home, it is the owner's taste, economic means, and overall circumstances that have shaped the home and its objects - both by acquiring them and by using or even throwing, selling, or giving them away. When turned into museums, open to the public, many houses have been restaged to an earlier appearance or a more pure aesthetic state. This restaging is often based on research done by art historians, and in many cases favours a purity of style or the ability of the curator to tell a coherent story of the house. The materiality of the house is thus adapted.

Objects in the historic house museum write their biographies, so to speak, as they constantly go through a series of transformations and presentations. As art historians, we can try to 
36 follow their movement through time and space. Analyzing these trajectories is a methodological way of illuminating the human and social context of things (Appadurai 1986:5). However, when we reach the present, we might end up with a complex situation, where we experience that all times exist, and that they collide or interact, even with the future of the object. This is a situation that might pose a problem for the art historian, because "if the object 'breaks' time, then the history of art is necessarily an 'anachronistic' enterprise" (Moxey 2008:135).

Apart from the very fabric of the houses themselves, they are filled with things, and the very materiality of it all can be rather overwhelming from both a practical and a theoretical perspective. What do art historians do with this overwhelming materiality? After a textual focus in the 1980s and onwards, today the physical stuff is given more attention. "The 'iconic' or 'pictorial turn' of art history which started in the 1990s adds the dimensions of presence to art history, and reminds us that visual artefacts refuse to be confined by the interpretations placed on them in the present" (Moxey 2008:135). Art could now be understood through its materiality and the experience of the viewer. Different art historic traditions place different weight on the study of objects. However, if we content ourselves with studying the image of materiality, it can, in fact, leave us half-blind when entering a historic building. Perhaps clinging to the image is a reaction based on the fear of realizing that studying the materiality of things requires facing up to an impure reality, a reality that time and the changing uses of heritage has left us.

\section{Conclusion}

There are several reasons as to why artistic or scenographic interventions are initiated in historic houses. One driving force is the experience industry, which demands more atmosphere and stories. And there is no doubt about it - interventions create new experiences by using all the senses, evoking feelings such as curiosity, sensuality, and adventure. They bring life into the house. They are also a response to the push for democratization, assisting in creating an atmosphere where more visitor groups feel welcome, and where the plurality of the past is recognized by generating new stories. This move can also give the historic house good will and increased exposure. Moreover, it is a way for historic house museums to have their visitors re-enter the house, to return and to engage with the house and its past.

What is our responsibility toward the future, or is survival based on being relevant today? Are we too prone to change or all too often so afraid of change that the historic house, as a consequence, might end up forgotten and abandoned? These questions cause us to wonder about the intention of the intervention and what restrictions there are to consider. The "outstanding strength of house museums is their totalising environment of real history", an asset that relies on the integrity of house museology (Young 2007:75). However, at the same time curators are asked to "let go of received truth as the only vector of understanding" and let visitors create their own understanding of the site (Young 2007:76). The intervention of an artist might cause controversy and pose uncomfortable questions about the real history of the site or the present use of the historic house. And even if the interventions are temporary, as was the case with Kensington Palace and Carl Eldhs Ateljémuseum, as described in the article, the way they were done might influence the practice of a permanent display of the building. New ideas about what stories 
should be told, how objects are displayed more effectively, or alternative interpretive methods might linger on. In this sense, installations can act as components in a process that ends up generating a new "metaphorical spirit of the place" (van Mensch 2012:14). And what should not be forgotten is that it works the other way around as well, the historic house museums provide a cultural, spatial, and temporal context that can transform our understanding of a contemporary artwork.

The historic house museum, then, can be fertile ground for integrating the fields of art history and critical heritage studies and studies of them can contribute new perspectives to both disciplines. Analyzing scenographic and artistic interventions and interactions with historic house museums can help us explore the definitions, uses, and ideas of heritage as well as those of art. Art historians should use this opportunity to re-enter the historic house and see what they find.

\section{Notes}

1. 18 , Folgate Street was visited by the author on 26 June 2013.

2. E.g. Waterton \& Watson 2010, Convery, Corsane \& Davis 2012, Hyde \& Scott, 2014.

3. I have visited these sites as part of my fieldwork for my upcoming dissertation Staging Cultural Heritage in Sweden 1970-2010. Art History and the Retro-Gustavian, Department of Art History, Uppsala University (planned publication 2016).

4. One of the most popular artists used for these interventions/interactions is filmmaker Peter Greenaway, who has worked with video installations in e.g. Castle Amerongen, Holland (2011), La Venaria Reale, Italy (2007).

5. DEMHIST annual conferences Catching the Spirit, 2011, Antwerp, and National symposium Konstvetenskapen och de historiska husen, 2014,
Uppsala University, Department of Art History,

Sweden.

6. Two recent examples are Milano 2014, MäkiPetäjä 2014.

7. As part of a categorization project launched by DEMHIST, the following categories were defined in 2007: Personality houses, collection houses, houses of beauty, historic event houses, local society houses, ancestral homes, power houses, clergy houses, and humble homes (Bryant \& Berens 2007). Linda Young identifies the following "intellectual" categories in her article "Is there a museum in the house? Historic houses as a species of museum": Hero, collection, design, historic event or process, sentiment, and country house museum (Young 2007).

8. A historic house can be a site for visitors without specifically defining themselves as museums. Instead, there are numerous types of selfidentification. An international committee more specifically dedicated to historic house museums was created in 1998, DEMHIST, by the ICOM (Pinna 2001).

9. This is something that was confirmed both in the documentary The House That Wouldn't Die, BBC4, 24 April 2005 and at the conference DEMHIST annual conferences Catching the Spirit, 2011.

10. Reviews from visitors can e.g. be found at All in London, "The latest user reviews of Enchanted Palace", http://www.allinlondon.co.uk/enchantedpalace-kensington-palace.php (dated 2010-211).

11. Interview with museum director Åsa CavalliBjörkman 28 January 2015.

\section{REFERENCES}

\section{Interviews}

Interview, museum director at Carl Eldhs Ateljémuseum Åsa Cavalli-Björkman 28 January 2015. 


\section{Internet sources}

All in London, "The latest user reviews of Enchanted Palace", http://www.allinlondon.co.uk/enchantedpalace-kensington-palace.php (accessed 20 December 2014)

Anon. C-print 5 October 2013. "Turning sculpturing upside down", C-print, http://www.c-print.se/\#!archive/c4ba/turningsculpturing-upside-down (accessed 1 December 2014)

Arts Council England 24 August 2011. museumaker, http://www.artscouncil.org.uk/funding/fundedprojects/case-studies/museumaker/ (accessed 30 November 2014)

BBC4, The House That Wouldn't Die, broadcasted on 24 April 2005 https://www.youtube.com/ watch?v=eAjZWZwxg_g (accessed 1 December 2014)

Carl Eldhs Ateljémuseum, "Charlotte Gyllenhammar", http://www.eldhsatelje.se/index.php/se/ utstallning/tidigare-utstal/\#.VJ2iNkAJAk, undated, (accessed 28 November 2014)

Château de Versailles spectacles, http://www.chateauversailles-spectacles.fr/en/ spectacles/2014/contemporary-art, (accessed 17 December 2014)

Dennis Severs' House, http://www.dennissevershouse. co.uk/the-tour/, (accessed 15 December 2014)

\section{Newspapers}

Battersby, Matilda 2010. "Enchanted Palace. Tale of seven princesses." The Independent 26 March. http://www.independent.co.uk/artsentertainment/art/features/enchanted-palace-atale-of-seven-princesses-1928374.html (accessed 28 December 2014)

Chrisafis Angelique 2008. "King of kitsch invades sun king's palace." The Guardian 9 September. http://www.theguardian.com/artanddesign/2008/ sep/09/art.france (accessed 29 December 2014)

Gardner, Lyn 2010. “The Enchanted Palace." The Guardian 13 April. http://www.theguardian.com/stage/2010/apr/13/ enchanted-palace-review (accessed 28 December 2014)

Persman Joanna 2013. "Eldh möter svalt intellekt." Svenska Dagbladet 11 August. http://www.svd.se/ kultur/konst/eldh-moter-svalt-intellekt_8414180. svd (accessed 1 December 2014)

Stamp Gavin 2000. Obituary Dennis Severs. The Guardian 10 January. http://www.theguardian. com/news/2000/jan/10/guardianobituaries (accessed 26 December 2014)

Wingfield Jonathan 2010. "Let them eat manga. How Takashi Muramaki introduced Japanese kitsch to the Palace of Versailles." The Independent 16 October. http://www.independent.co.uk/artsentertainment/art/features/let-them-eat-mangahow-takashi-murakami-introduced-japanesekitsch-to-the-palace-of-versailles-2105842.html (accessed 29 December 2014).

\section{LITERATURE}

Aldrich, Megan Brewster \& Jos Hackforth-Jones (eds.) 2012. Art and Authenticity. Farnham: Lund Humphries in association with Sotheby's Institute of Art.

Appadurai, Arjun (ed.) 1986. The Social Life of Things. Commodities in Cultural Perspective. Cambridge: Cambridge Univ. Press.

Arnold-de Simine, Silke 2013. Mediating Memory in the Museum. Empathy, Trauma, Nostalgia. Houndmills, Basingstoke, Hampshire: Palgrave Macmillan.

Bryant, Julius 2007. "Curating the Georgian interior. From period rooms to market place?" Journal of Design History 20:4, 345-350.

Bryant, Julius \& Berens, Hetty 2007. “The DEMHIST categorisation project for historic house museums" http://www.demhist.icom.museum/ shop/shop.php?detail=1281086966, (accessed 26 December 2014)

Convery, Ian, Gerard Corsane \& Peter Davis (red.) 
2012. Making Sense of Place. Multidisciplinary Perspectives. Woodbridge: Boydell.

Donnelly, Jessica Foy (ed.) 2002. Interpreting Historic House Museums. Walnut Creek, CA: AltaMira Press.

Hede, Anne-Marie \& Maree Thyne 2010. "A journey to the authentic. Museum visitors and their negotiation of the inauthentic." Journal of Marketing Management 26:7, 686-705.

Hyde, Melissa Lee \& Katie Scott (eds.) 2014. Rococo Echo. Art, History and Historiography from Cochin to Coppola. Oxford: Voltaire Foundation.

Kirshenblatt-Gimblett, Barbara 1998. Destination Culture. Tourism, Museums, and Heritage. Berkeley: Univ. of California Press.

Mäki-Petäjä, Kaisa 2014. Aesthetic Engagement in Museum Exhibitions. Jyväskylä: University of Jyväskylä.

Marstine, Janet (ed.) 2005. New Museum Theory and Practice. An Introduction. Malden, MA: Blackwell.

McEvoy, Emma 2011. "Dennis Severs' house. Performance, psychogeography and the Gothic." Visual Culture in Britain 12:2, 185-201.

Milano, Ronit 2014. “(Re)Staging art history. Jeff Koons in Versailles." Museum and Curatorial Studies Review 2:1, 39-66.

Moore, Kevin 1997. Museums and Popular Culture. London: Leicester Univ. Press.

Moxey, Keith 2008. "Visual studies and the iconic turn." Journal of Visual Culture 7:2, 131-146.

Pavoni, Rosanna 2001. "Towards a definition and typology of historic house museums". Museum International (UNESCO, Paris) No 210, 53:2, 16-21.

Pinna, Giovanni 2001. "Introduction to historic house museums." Museum International, No. 210, 53:2, 4-9.

Risnicoff de Gorgas, Mónica 2001. "Reality as illusion, the historic houses that become museums." Museum International (UNESCO, Paris), No 210, 53:2, 10-15.

Serota, Nicholas 2001. "Housing modern art." RSA Journal 148:5497. van Hoof, Werner (ed.) 2012. The ICOM/DEMHIST International Conference Antwerp. Antwerpen: Museum Platin-Moretus.

Vergo, Peter (ed.) 1989. The New Museology. London: Reaktion.

Waterton, Emma \& Watson, Steve (eds.) 2010. Culture, Heritage and Representation. Perspectives on Visuality and the Past. Farnham: Ashgate.

Wright, Patrick. \& Krauze, Andrzej 2009. On Living in an Old Country. The National Past in Contemporary Britain. [Updated ed.] Oxford: Oxford University Press.

Young, Linda March 2007. "Is there a museum in the house?" Museum Management and Curatorship 22:1, 59-77.

Hedvig Mårdh, MA International Museum

Studies, Ph.D. candidate Art History

hedvig.mardh@konstvet.uu.se

Department of Art History, Uppsala University Box 630

SE-751 26 Uppsala, Sweden 